\title{
The Role of Adult and Non-Formal Education in the Eradication of Hatespeech as a Catalyst for National Disintegration in Nigeria
}

\author{
Olajide Muili Folaranmi Ph. D* Danladi Cassidy C. H. \\ Department of Continuing Education and Community Development \\ brahim Badamasi Babangida University, Lapai, Niger State, Nigeria.
}

\begin{abstract}
Hate is among the most powerful of human emotions - it has caused great suffering - and yet it has been understudied by psychologists. The study was conducted to assess the role of adult and non-formal education in the eradication of hate speech as a catalyst for national disintegration." Hate speech undermines the essence of public good. "When a society is defaced with anti-Semitic signage, burning crosses and defamatory racial leaflets," the assurance of security "evaporates." The study set out with the objectives of finding out the causes of hate in the society; to evaluate the strength and implications of language use; to ascertain the disintegrating socioeconomic effects of hatespeech if left to continue; to ascertain the level of government commitment of fostering unity among its geopolitical zones and to ascertain the strategies to be employed in addressing hatespeech and helping those affected by verbal and non-verbal abuse. A simple random sampling technique was used to sample 90 respondents. The simple frequency and percentage was used to analyse the data gotten. The results arrived at include that Freedom of speech, though sacrosanct, is not absolute. Our freedom is a shared one, limited by the freedom of others. Citizens must draw the line between free speech and arbitrary spite. For a multi-ethnic state with fault lines such as ours, the lasting solution lies in healing the cleavages that promote ethnic division. This also means the triumph of a national identity that transcends the opportunistic ethnocentric group identity, which has been the bane of Nigeria's nationhood. On this note this research seeks to reiterate the call for the restructuring of Nigeria in a manner of true federalism.
\end{abstract}

Keywords: Adult, Non-Formal Education, Eradication, Hatespeech, National Disintegration.

DOI: $10.7176 / \mathrm{JEP} / 10-9-20$

Publication date:March $31^{\text {st }} 2019$

\section{Introduction}

Hate is among the most powerful of human emotions - it has caused great suffering - and yet it has been understudied by psychologists. After the genocide perpetrated by the Nazis in World War II, the expression "Never Again" became a familiar refrain. Yet, during the last half of the twentieth century, and the beginning of the current decade, society has witnessed staggering numbers of brutal hateful acts.In his engaging new book, "The Harm in Hate Speech," the legal philosopher Jeremy Waldron begins with the premise that in a "well-ordered society" not only must all people be protected by the law; they are entitled to live in confidence of this protection. "Each person ... should be able to go about his or her business, with the assurance that there will be no need to face hostility, violence, discrimination or exclusion by others." Hate speech undermines this essential public good. "When a society is defaced with anti-Semitic signage, burning crosses and defamatory racial leaflets," Waldron says, this assurance of security "evaporates.”(McConnell, 2012)

Nigeria faced many problems between 2015 and 2017. A power vacuum was created by the poor health of President Muhammadu Buhari, carnage was wrought in Nigeria's north by the Islamist terror group Boko Haram, and more than 14 million people needed humanitarian aid after a dreadful famine. Amidst Nigeria's many problems, the story of Nigeria's ethnic conflict has however been largely untold and yet it may cause Nigeria to split into multiple nations. The tensions of Nigeria's civil war have not gone away. Many Igbo people have called for the independence of Biafra, in Nigeria's south-east, which was last independent during Nigeria's civil war, from 19671970. Biafra was dissolved into the Federal Republic of Nigeria after the conflict, which culminated in millions of deaths and there have been concerns that hate speech may cause a return to violence. Radio Biafra was accused of hate speech and of "inciting its listeners to violence while canvassing for a secession from Nigeria." (Snaddon, 2017)

"Hate speech lies in a complex nexus with freedom of expression; individual, group and minority rights; "and concepts of dignity, equality and safety of person." (UNESCO report, 2015).The 1993,1999 and 2000 riots in Kaduna, 2017 and 2018 herdsman killings in southern Kaduna, parts of Benue, Nassarawa, and Ekiti, the communal clashes in Kwara, Kogi and other parts of Nigeria to mention but a few are not random or sudden bursts of irrationality but rather carefully planned and orchestrated acts of violence and killings. Underlying these events is the widespread and hazardous human emotion: hate.

The tension in the land can be described as palpable. In the wake of this decade, ballistic verbal missiles of ethnocentric proportions have been flying across both sides of the Niger. Apart from the abundant lessons in our unfortunate Civil War, the Rwandan genocide of 1994 provides an easy reference. Threats of war, eviction notices 
and other hubris that tend to undermine our national security are increasingly becoming part of our socio-political reality this moment. Unfortunately, apart from unbridled rhetoric, nothing concrete is being done about the whole ensemble by the authorities and the situation is getting worse by the day. Hate messages are being spread with reckless abandon on the social media. Otherwise decent and respectable men are joining the fray with divisive and vitriolic statements. Before it is too late, the "combatants" should be called to order.

The ongoing hate speeches and divisive comments in Nigeria are a sad reminder that we have failed to learn from our past mistakes and those of other countries. The perennial tribal bigotry is a time bomb waiting to explode, and for a country that has a poor record of nipping crises in the bud and equally found wanting in crises management, we need to go beyond mere rhetoric and issuing threats not backed by action on perpetrators. Perhaps, these divisive and seditious schemes may be preparatory to delude us into a bigger problem capable of bringing the country to the brink of disintegration. Thus the essence for carrying out this study on the role of adult and nonformal education in eradicating hatespeech as a catalyst for national disintegration.

\subsection{Definition of Concepts}

1. Education: Education is the industry that produces manpower for the economy of nations and as such, education enhances manpower development by improving the number and quality of human resource.

2. Adult Education: Education given to any person regarded as an adult by the society in order to socially, economically and culturally improve and empower himself or herself so that the person will be able to contribute meaningfully as a useful and acceptable member of society.

3. Non-Formal Education: Education given to adults outside four walls of school system.

4. Hate, Speech, Hatespeech: The concept is a complex one. For proper understanding it is broken down into separate words and combined together give a clearer picture;

- Hate: A deep and extreme emotional dislike, especially invoking feelings of anger or resentment which can be directed against individuals, groups, entities, objects, behaviors, or ideas. Hatred is often associated with feelings of anger, disgust and a disposition towards hostility.

- Speech: Is the communication or expression of thoughts through spoken words.

- Hatespeech: Is speech which attacks a person or group on the basis of attributes such as race, religion, ethnic origin, sexual orientation, disability, or gender.

\section{LITERATURE REVIEW}

Nigeria is a federated state with over 250 ethnic groups and 500 languages. The survival of our over 180 million people lies in our ability to curtail conflicting ethnic tensions. We have, however, had instances of conflict along ethno-religious lines, most notably the civil war in the period 1967 to 1970 which saw millions of Nigerian citizens killed. The "us" against "them" rhetoric that ignited bloodshed of a bestial magnitude since independence has resurfaced again. A new breed of ethnic entrepreneurs seems hell-bent on causing anarchy for political motives. The lessons of our history are being ignored. Strength in diversity is considered weakness. And in 2007, a group of Nigerian writers released an article on "Ethnic Hate Speech" detailing with grave concern the dominance of ethnic incendiary speech in the country. They also expressed their deep trouble that the public space-both online and offline- has been hijacked by a vocal minority of individuals who promote ethnocentric ideas inimitable to the peace and wellbeing of a majority of citizens. Nigerian citizens have a right to freely express their opinions on governance as enshrined in the Constitution. However, this fundamental right of freedom of speech is being used to disseminate hate speech, which goes contrary to the right itself and the spirit of the Constitution that enshrines it. Nigeria's democracy, attained through great sacrifice and loss, now faces its most crucial test of ensuring that citizens are safe wherever they choose to reside, be it in the north-east, north-west, north-central, south-east, southwest, or south-south. (Egbunike N. et al, 2017).

On this premise, this paper will seek to review literature on the concepts below.

2.1 The Concept of Adult Education: Adult education as a concept has no specific definition because of its wide scope and the multiplicity of activities and programmes designed at different points in time in the lives of individuals for their better adaptation to the changes in the environment and society. Adult education which is an important part of education is a catalyst for national development and transformation. According to United Nation Educational, Scientific and Cultural Organization (UNESCO) in Ugwegbu (1992), "adult education is the process by which men and women alone, in groups, or in institutional settings seek to improve themselves or their society by increasing their skills, their knowledge, their sensitiveness, thus, any process by which individuals, groups or institutions try to help men and women improve in these ways" is adult education. It is in view of the important role of adult education in national development and transformation, that Nyerere in Ugwegbu (1992) stated that people must develop first before the nation can develop stressing that we must educate adults since children will not have immediate impact on the economic development of the nation. Adult education is the education 
provided for adults based on their social, political, cultural and economic needs or problems (Nzenri, 2002). These definitions of adult education trigger the fact that the adult population form the human resource needed for national development and to also contribute meaningfully to nation building and transformation.

2.2 Adult Education and the Society: Adult education is change-oriented. It is the type of education planned to bring about positive change to the adult who will invariably bring positive change in the society. According to Egwu (2012), Nigeria is currently undergoing rapid changes economically, socially, politically, culturally and technologically and to meet the challenges in the fast changing world, adult education becomes a vital instrument for a society undergoing such changes. It is vital to note that adult education is any programme designed to enable people improve their lives and maximize their potentials in whatever profession of their choices regardless of age and prior levels of education. When the human resource is maximized, the society stands to benefit.

2.3 Adult Education and Communication: Adult education is a versatile area of study that has grown to become one that has been strengthened through the use Information and Communication Technology (ICT) equipment. This is so because adult education touches all aspects of human endeavours and the integration of ICT equipment in adult education has engendered positive development in actualizing societal goals associating with the terrain of computer age. Adult education over time facilitated the addressing of socio-economic, cultural, political and environmental problems that has besought humanity in various societies whether underdeveloped, developing or developed. This is so because adults are the major occupants of the production sectors of the economy. Fasakun (2006) observed that adult education is not concerned with preparing people for life but rather with helping or assisting people (adults) to live more successfully as useful and acceptable members of their societies and contribute meaningfully to the development of those societies.

Nzeneri (2010) clearly stated that:

Our $21^{\text {st }}$ century is characterized by an upsurge and surely we have not stopped talking about technological transfer. A century where communication and infrastructural facilities may no longer play ties such as telephones, fax and computer networking are tools that are turning our word into a global village, where classroom may no longer play prominent roles as major access to education.

Igbo (2008) observes that adult education is an instrument for helping the active population worldwide with information and communication technology (ICT), which is a decisive tool for the smooth integration of Nigerian economy in the global economy. Thus, for adults not to be left out in what is happening in the world they need to key into the use and application of this technology and this can only be achieved through the integration of ICT into adult education in Nigeria.

2.4 The Concept of Hatespeech: Generally, hate speech can be broadly defined as a speech act that antagonizes or marginalizes people based on their identification with a particular social or demographic group. It is the result of a communication processes that compromise human dignity, equality and human rights. However, definitions of hate speech can be contentious and problematic, given tensions between the labelling of a harmful speech act as such, which has the potential to antagonize or marginalize an individual or group, and those speech acts that contribute to a pluralistic debate on a particular issue. Hate speech is a type of discriminatory speech that arises when people from different social, ethnic, or religious groups interact with one another, or when one such group asserts its power over others. There are many different ways of describing hate speech in more detail, but one definition is as follows: "Hate speech is defined as a bias-motivated, hostile, malicious speech aimed at a person or a group of people because of some of their actual or perceived innate characteristics. It expresses discriminatory, intimidating, disapproving, antagonistic, and/or prejudicial attitudes toward those characteristics, which include gender, race, religion, ethnicity, color, national origin, disability, or sexual orientation. Hate speech is aimed to injure, dehumanize, harass, intimidate, debase, degrade, and victimize the targeted groups and to foment insensitivity and brutality against them" (Cohen-Almagor, 2013).

2.5 Freedom of Speech versus Hatespeech: The term "freedom of speech" is used to capture those discursive acts - often political in nature - that can be imparted or received, without constraint or censorship, particularly on the part of government authorities. It is also known according to other terms such as "freedom of expression," or in certain legislative contexts, "freedom of the press". These can be in the form of spoken or written words, but can also be actions or thoughts expressed through artistic or performative means. Indeed, any channel can communicate these speech acts, including print, visual, broadcast, and online media. Freedom of speech is therefore a layered and multi-faceted concept, and encompasses several debates on fundamental political concepts and philosophies, their interpretation, as well as their regulation. 
Tensions between hate speech and freedom of speech become apparent with speech acts that intentionally seek to violate or denigrate an individual's membership to a particular socio-economic, demographic or political group. Navigating through these tensions invites a consideration of the repercussions of limiting or encouraging freedom of expression, including the defence of hate speech, and whether or not this significantly affects a person or group's right to human dignity (Barendt, 2005: 5). The universal right to "human dignity" is therefore intrinsically connected to the protection of fundamental political rights and freedoms. Freedom of speech and hate speech then becomes a point of contention when the balance between opinion and violations of human dignity are shifted, raising the issue of hate speech and international legislation.

2.6 Hatespeech on the Individuals and The Society: Free speech is sacred to any democratic society. However, the sometimes painful bite of unfettered speech leads many to ask two perfectly logical questions: At what cost? And for what pain? Those questions are particularly acute when asked about hatespeech, speech that causes considerable pain and offers little in the way of societal benefit. Treating people as moral subordinates means treating them in a way that makes them in a way that takes away their personal interests to be intrinsically less important, and their lives inherently less valuable than the interests of those who belong to the same reference group. There are many ways of treating people as moral subordinates that are natural as opposed to conventional: the status of these acts of subordination depends solely on universal principles of morality and not on the conventions of a given society. Slavery and genocide, for example, treat people as having inferior moral standing simply in virtue of their affront of such practices to universal moral principles.

It is commonly recognized that through language we can "Put people down" by using vernacular expressions. There are many modes of putting people down; putting them down as less intelligent, or less clever or less articulate or less skillful. Putting people down in this way is not identical to treating them as moral subordinates and the ordinary put down does not involve regarding someone as having inferior moral standing. The put downs that are accomplished with the slurs and epithets of hate speech are different from the ordinary verbal put-down in that respect even though both sorts of put down are done through language.

2.7 Hatespeech in the Cyber Space: Although hate speech expressed online has these specific characteristics, it is a fallacy to adapt the digital dualist assumption that anything happening online is separate from the offline, as argued by Jurgensen (2011): "Social media has everything to do with the physical world and our offline lives are increasingly influenced by social media". An example of this digital dualist assumption is institutions worrying about white supremacists using the web to recruit people, but not about the site in itself also being an outlet for racism (Daniels, 2009).

Hate speech as such is not a new issue in the human rights debate, its online dimension and the potential impact this offers gives new reasons for concern among young people and youth organizations. While easier to monitor and counter in mainstream professional media, the challenge posed by its online manifestation is the incapacity to monitor and measure its amplitude and impact. While the activity of static websites can be easily traced, most of the action is actually happening in the encounter spaces (i.e. social networking sites), which are far harder to monitor and analyse in the manner which shows its appropriateness. (Altman, 1993)

The Internet offers possibility for every user/participant to create, publish, distribute and consume media content that foster a space full of participation, engagement and self-expression. The development of social networks, in particular, has increased the level of youth participation in cyberspace in a variety of ways ranging from keeping in touch with peers and developing new contacts to sharing content and exploring self-expression. Online space, just as offline space, presents new opportunities, challenges and threats to young people. Just as in offline space, young people may equally be victims and agents of abuse and human rights violation. Interaction in online space among different participants in communication, even though democratic and uncensored, cannot and is not to be value-void.

\section{Methodology}

\subsection{Research Design}

The Descriptive research design was adopted for this study. This research design is appropriate because it allowed the researcher collect information from a large population.

\subsection{Population of the Study}

The population of the study cuts through a cross section of respondents taken from the six (6) geo-political zones of the Nigerian Federation aged 15 years and above. A sample size of 120 respondents participated in the study, 15 male and female respectively represented the 6 zones. This was achieved through a simple random sampling 
technique using the likert 4 point scale. The respondents were sampled in the main campus of Ibrahim Badamasi Babangida University, Lapai, Niger State, Nigeria. The respondents comprised staff and students.

\subsection{Distribution of the Sample Population}

\begin{tabular}{lccc}
\hline GEO-POLITICAL ZONE & MALE & FEMALE & SAMPLE POPULATION \\
\hline NORTH-EAST & 10 & 05 & 15 \\
NORTH-WEST & 10 & 05 & 15 \\
NORTH-CENTRAL & 10 & 05 & 15 \\
SOUTH-EAST & 10 & 05 & 15 \\
SOUTH-WEST & 10 & 05 & 15 \\
SOUTH-SOUTH & 10 & 05 & 15 \\
\hline & & & $\mathbf{9 0}$ \\
TOTAL & $\mathbf{6 0}$ & $\mathbf{3 0}$ & \\
\hline
\end{tabular}

\section{Research instruments}

A structured questionnaire with closed ended questions was used to sample opinions from the respondents on hatespeech in Nigeria. According to Bless et al. (2006) questionnaires reduce bias by the interviewer and encourage honesty by respondents as they require anonymity. The results were tabulated and analysed using descriptive analytic instruments like the simple frequency and percentages.

\subsection{Data Presentation and Analysis}

\section{Data Presentation}

Data collected was presented in tables and bar graphs. The response rate to the questionnaire was an impressive $100 \%$. All the respondents were cooperative.

\subsection{Figure 1: Demographic Data of Respondents}

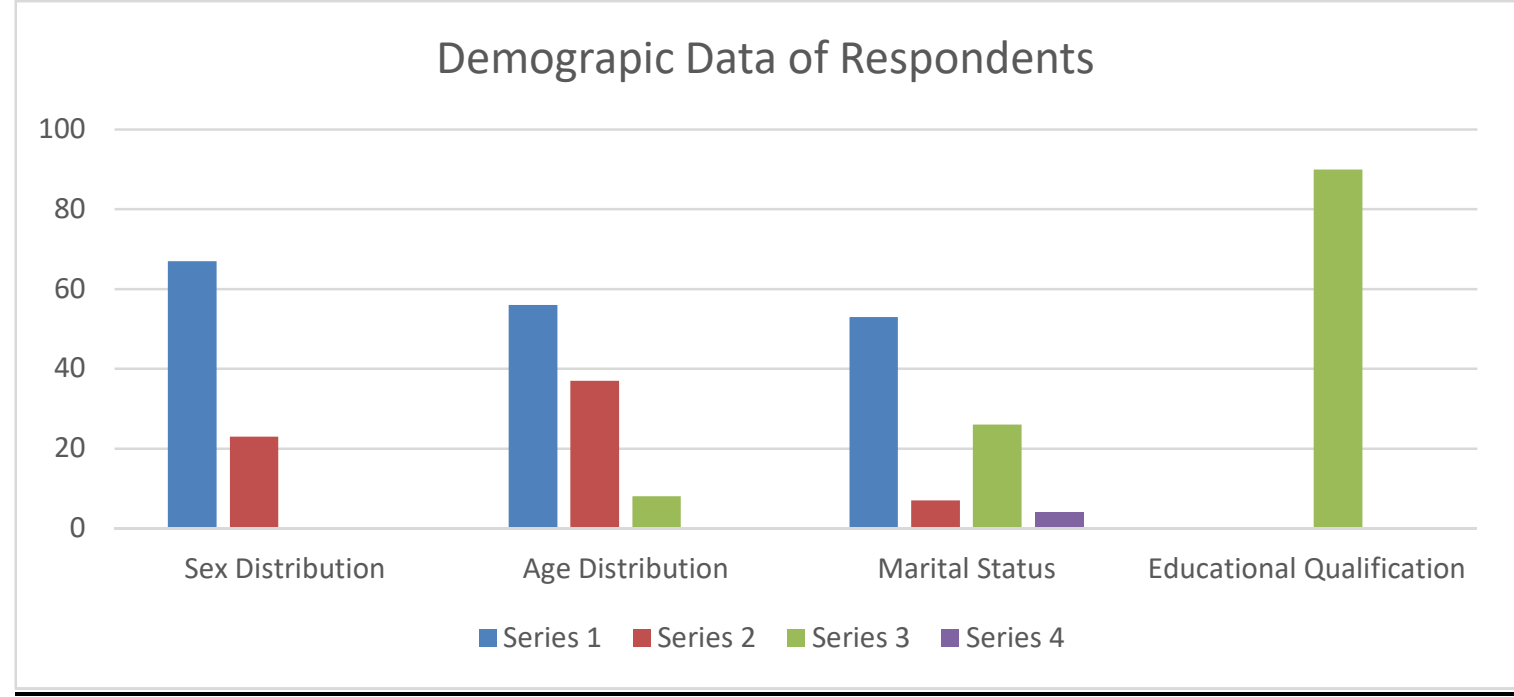




\subsection{Table 1: Demographic Data of the Respondents}

\begin{tabular}{|c|c|c|}
\hline Sex Distribution & Frequency & \\
\hline Male & 67 & \\
\hline Female & 23 & \\
\hline Total & 90 & \\
\hline Age Distribution & Male & Female \\
\hline $15-25$ & 39 & 11 \\
\hline $25-35$ & 24 & 9 \\
\hline 45 - above & 4 & 3 \\
\hline Total & 67 & 23 \\
\hline Sum total & 90 & \\
\hline Marital Status & Male & Female \\
\hline Single & 43 & 10 \\
\hline Engaged & 5 & 2 \\
\hline Married & 16 & 10 \\
\hline Divorced & 3 & 1 \\
\hline Total & 67 & 23 \\
\hline Sum total & 90 & \\
\hline Educational Qualification & Male & Female \\
\hline Basic & 0 & 0 \\
\hline O'level & 0 & 0 \\
\hline Tertiary & 67 & 23 \\
\hline Sum total & 90 & \\
\hline
\end{tabular}

\section{Source: Field Survey 2018}

With the aid of the chart in Figure 1, the table above summarises the demographic data of the respondents. Contained within is the sex, age, marital status and educational qualification of the respondents.

\subsection{Analysis}

Table 2: Percentage distribution of the respondent's opinion on the causes of hate among individuals in the society.

\begin{tabular}{|c|c|c|c|c|c|c|c|c|}
\hline \multirow[t]{2}{*}{ Sn. } & \multirow[t]{2}{*}{ Items } & \multirow{2}{*}{$\frac{\text { No. }}{\text { Valid }}$} & \multicolumn{2}{|c|}{ Agree } & \multicolumn{2}{|c|}{ Disagree } & \multirow{2}{*}{$\frac{\text { Total }}{\%}$} & \multirow[t]{2}{*}{ Remark } \\
\hline & & & Freq. & $\%$ & Freq. & $\%$ & & \\
\hline 1. & $\begin{array}{l}\text { Religious disparity causes people to hate their } \\
\text { neighbors. }\end{array}$ & 90 & 72 & 80 & 18 & 20 & 100 & AGREE \\
\hline 2. & $\begin{array}{l}\text { Political party affiliations causes hate among } \\
\text { people. }\end{array}$ & 90 & 76 & 84.4 & 14 & 15.6 & 100 & AGREE \\
\hline 3. & Ethnicity can also cause hate among people. & 90 & 70 & 77.8 & 20 & 22.2 & 100 & AGREE \\
\hline 4. & $\begin{array}{l}\text { Academic achievement can cause hate among } \\
\text { people especially students. }\end{array}$ & 90 & 61 & 67.8 & 29 & 32.2 & 100 & AGREE \\
\hline 5. & $\begin{array}{l}\text { When people are cheated on the basis of } \\
\text { socio-economic status, it could stir up hate in } \\
\text { them? }\end{array}$ & 90 & 82 & 91.1 & 8 & 8.9 & 100 & AGREE \\
\hline
\end{tabular}

\section{Source: Field Survey 2018}

From the table above, there is a clear indication that a large percentage of the respondents agree with the items presented in this section. This indicates that, even though some respondents chose to disagree, no doubt $80 \%$ agreed that religious disparities can cause hate among individuals while $20 \%$ disagreed. $84.6 \%$ agreed that partisan political affiliations and sentiments can cause hate among individuals $15.6 \%$ disagreed. $77.8 \%$ agreed that ethnicity can cause hate among individuals while 22.2\%. 67.8\% agreed that academic achievement can cause hate among individuals and an overwhelming $91.1 \%$ agreed that the situation where people are cheated on the basis of socioeconomic status are among the many reasons that can cause a stir of hate among individuals in the society $8.9 \%$ disagreed. 
5.5 Table 3: Percentage distribution of the respondents opinion onthe implications of language use on individuals.

\begin{tabular}{|c|c|c|c|c|c|c|c|c|}
\hline \multirow{2}{*}{ Sn. } & \multirow[t]{2}{*}{ Items } & \multirow{2}{*}{$\begin{array}{l}\text { No. } \\
\text { Valid }\end{array}$} & \multicolumn{2}{|c|}{ Agree } & \multicolumn{2}{|c|}{ Disagree } & \multirow{2}{*}{$\frac{\text { Total }}{\%}$} & \multirow[t]{2}{*}{ Remark } \\
\hline & & & Freq. & $\%$ & Freq. & $\%$ & & \\
\hline 6. & $\begin{array}{l}\text { Language use can lead to negative } \\
\text { stereotyping. }\end{array}$ & 90 & 83 & 92.2 & 7 & 7.8 & 100 & AGREE \\
\hline 7. & Insensitive remarks can demoralize a person. & 90 & 70 & 77.8 & 20 & 22.2 & 100 & AGREE \\
\hline 8. & $\begin{array}{l}\text { Name-calling and ridicule can affect a } \\
\text { persons character. }\end{array}$ & 90 & 71 & 78.9 & 19 & 21.1 & 100 & AGREE \\
\hline 9. & $\begin{array}{l}\text { Vocal bullying / abuse can seriously reduce a } \\
\text { persons self-esteem. }\end{array}$ & 90 & 72 & 80 & 18 & 20 & 100 & AGREE \\
\hline 10. & $\begin{array}{l}\text { Dehumanization through language can cause } \\
\text { social-avoidance by the victim. }\end{array}$ & 90 & 76 & 84.4 & 14 & 15.6 & 100 & AGREE \\
\hline
\end{tabular}

\section{Source: Field Survey 2018}

From the table above, a huge percentage of the respondents also agreed as regards to those who disagreed to the fact that language use whether positive or negative has a lot of implications on individuals in the society which could foster hate and irrational behavior. Language use as agreed by $92.2 \%$ the respondents could lead to negative stereo-tying while $7.8 \%$ disagreed. $77.8 \%$ agreed that insensitive remarks could also demoralize individuals $22.2 \%$ disagreed. $78.9 \%$ agreed that name calling and ridicule can affect a persons character, however, $21.1 \%$ disagreed and of course $80 \%$ agreed that vocal bullying or other forms of vocal abuses can seriously reduce a persons selfesteem while $20 \%$ disagreed. All these variables could go a long way to imprinting hate in individuals towards the perpetrators which could result in transferred aggression. As an extension, $84.4 \%$ agreed that dehumanization through language can cause serious social avoidance by the victim, however, $15.6 \%$ disagreed.

5.6 Table 4: Percentage distribution of the respondents opinion on the possible disintegrating socioeconomic effects of hatespeech.

\begin{tabular}{|c|c|c|c|c|c|c|c|c|}
\hline Sn. & Items & No. & $\overline{\text { Ag }}$ & & $\overline{\text { Disa }}$ & $\overline{\text { ree }}$ & Total & Remark \\
\hline & & Valid & Freq. & $\%$ & Freq. & $\%$ & $\%$ & \\
\hline 11. & Hate can lead to economic discrimination. & 90 & 80 & 88.9 & 10 & 11.1 & 100 & AGREE \\
\hline 12. & $\begin{array}{l}\text { Hate can also lead to discrimination in terms } \\
\text { of education and employment. }\end{array}$ & 90 & 78 & 86.7 & 12 & 13.3 & 100 & AGREE \\
\hline 13. & $\begin{array}{l}\text { Hate can lead to the slow growth of a country } \\
\text { in terms of diffusion and development. }\end{array}$ & 90 & 74 & 82.2 & 16 & 17.8 & 100 & AGREE \\
\hline 14. & $\begin{array}{l}\text { Hate could lead to political discrimination, } \\
\text { social injustice, and sexual / gender bias. }\end{array}$ & 90 & 79 & 87.8 & 11 & 12.2 & 100 & AGREE \\
\hline 15. & $\begin{array}{l}\text { If left unchecked, hatespeech could lead to } \\
\text { genocide. }\end{array}$ & 90 & 79 & 87.8 & 11 & 12.2 & 100 & AGREE \\
\hline
\end{tabular}

Source: Field Survey 2018

From the table above, the respondents agreed to the fact that if left unchecked and addressed properly, hate speech has a host of disintegrating socio-economic effects. These effects can be seen in countries that are still struggling with the devastating aftermath of conflicts that arose as a result of hate and hatespeech. It was generally agreed by a high percentage that hate can lead to economic discrimination in terms of education and employment, it could lead to the slow growth of a country in terms of diffusion and development, not to ignore discrimination in terms of polity, social justice, sexual and gender bias. By a long shot however, it was also agreed that if left unchecked, hatespeech could lead the complete annihilation of a people through genocide as seen in countries like Rwanda 1994. 
5.7 Table 5: Percentage distribution of the respondents opinion onhow committed government is in fostering unity among its geo-political zones.

\begin{tabular}{|c|c|c|c|c|c|c|c|c|}
\hline Sn. & Items & No. & \multicolumn{2}{|c|}{ Agree } & \multicolumn{2}{|c|}{ Disagree } & Total & Remark \\
\hline 16. & $\begin{array}{l}\text { Government has made efforts to caution } \\
\text { perpetrators. }\end{array}$ & $\begin{array}{c}\text { Valid } \\
90\end{array}$ & $\begin{array}{c}\text { Freq. } \\
57\end{array}$ & $\begin{array}{c}\% \\
63.3\end{array}$ & $\begin{array}{c}\text { Freq. } \\
33\end{array}$ & $\begin{array}{c}\% \\
36.7\end{array}$ & $\begin{array}{c}\% \\
100\end{array}$ & AGREE \\
\hline 17. & $\begin{array}{l}\text { Government has identified hate as a common } \\
\text { enemy and recognized the need to unite } \\
\text { factions. }\end{array}$ & 90 & 58 & 64.4 & 32 & 35.6 & 100 & AGREE \\
\hline 18. & $\begin{array}{l}\text { Government has embarked on social media } \\
\text { campaigns to sensitize people on the dangers } \\
\text { of hatespeech. }\end{array}$ & 90 & 53 & 58.9 & 37 & 41.1 & 100 & AGREE \\
\hline 19. & $\begin{array}{l}\text { Government has organized town hall } \\
\text { meetings and community development } \\
\text { initiatives through outreaches to reach out to } \\
\text { the people at the grassroots. }\end{array}$ & 90 & 43 & 47.8 & 47 & 52.2 & 100 & AGREE \\
\hline 20. & $\begin{array}{l}\text { Government has increased security in all its } \\
\text { geo-political zones. }\end{array}$ & 90 & 39 & 43.3 & 51 & 56.7 & 100 & AGREE \\
\hline
\end{tabular}

Source: Field Survey 2018

From the table above, the percentage of respondents who agreed in favor of Governments commitment to fostering unity among its geopolitical zones varied insignificantly to those who disagreed. Nevertheless, going by the antecedence of our ugly civil war days, it is clear that $63.3 \%$ agreed that government have tried and are still trying to caution perpetrators while $36.7 \%$ disagreed. $64.4 \%$ agreed and $35.6 \%$ disagreed that government has identified hate as a common enemy and seen the need to unite its factions. It was also agreed by $58.9 \%$ that government has tried to engage the media in campaigns to sensitize people on the dangers of hatespeech while $41.1 \%$ disagreed. However, $52.3 \%$ agreed that government has done not so much on the aspects of grassroot mobilization through townhall meetings and community development initiative through outreaches to reach out to the people in the hinter lands while $47.8 \%$ agreed contrary. Also, on a low side, a significant percentage of the respondents of about $56.7 \%$ disagreed to the fact that government has increased security in all its geopolitical zones with the widespread extra judicial killings flooding news channels while $43.3 \%$ agreed.

5.8 Table 6: Percentage distribution of the respondents opinion on strategies that can be employed to address hatespeech especially to those who are victims of abuse: both verbal and non-verbal.

\begin{tabular}{|c|c|c|c|c|c|c|c|c|}
\hline Sn. & Items & No. & Ag & & Disa & ree & Total & Remark \\
\hline & & Valid & Freq. & $\%$ & Freq. & $\%$ & $\%$ & \\
\hline 21. & $\begin{array}{l}\text { The preaching of religious tolerance can help } \\
\text { address hatespeech. }\end{array}$ & 90 & 85 & 94.4 & 5 & 5.6 & 100 & AGREE \\
\hline 22. & $\begin{array}{l}\text { Mass media campaigns showing the effects of } \\
\text { hatespeech on other countries can address } \\
\text { hatespeech. }\end{array}$ & 90 & 71 & 78.9 & 19 & 21.1 & 100 & AGREE \\
\hline 23. & $\begin{array}{l}\text { Bullying, insults, name-calling and other } \\
\text { forms of verbal and non verbal abuses should } \\
\text { be purnished in schools especially primary } \\
\text { and secondary levels. }\end{array}$ & 90 & 83 & 92.2 & 7 & 7.8 & 100 & AGREE \\
\hline 24. & $\begin{array}{l}\text { Treating people accordingly, regardless of } \\
\text { ethnic, gender or socio-economic status can } \\
\text { help address the issue of hatespeech. }\end{array}$ & 90 & 79 & 87.8 & 11 & 12.2 & 100 & AGREE \\
\hline 25. & $\begin{array}{l}\text { When all zones are treated equally and fairly } \\
\text { in terms of allocations and appointments } \\
\text { regardless of size or ethnicity. }\end{array}$ & 90 & 82 & 91.1 & 8 & 8.9 & 100 & AGREE \\
\hline
\end{tabular}

Source: Field Survey 2018

From the table above, the respondents agreed to the suggestions offered by a high percentage while a slim percentage disagreed. $94.4 \%$ agreed that through the preaching of religious tolerance $5.6 \%$ disagreed, $78.9 \%$ agreed that intensified media campaigns showing the effects of hatespeech on other countries, $21.1 \%$ disagreed. $92.2 \%$ agreed that bullying, insults, name-calling and other forms of verbal and non verbal abuses should be purnished in schools especially primary and secondary levels was another variable that the respondents agreed to while $7.8 \%$ disagreed. Also, 12.2 disagreed yet $87.8 \%$ of the respondents agreed that treating people accordingly, regardless of ethnic, gender or socio-economic status could help address the issue of hatespeech concurring with 
91.1\% to the fact that when all zones are treated equally and fairly in terms of allocations and appointments regardless of size or ethnicity hatespeech can be reduced to a bare minimum, however, $8.9 \%$ disagreed.

\section{Discussion}

The study was carried out to find out what role adult and non-formal education can play in eradicating hatespeech as a catalyst for national disintegration. Its rationale derives from the ballistic missiles crisscrossing the Nigerian hemisphere. The idea is that adult education can be utilized in creating an awareness that we are stronger together than apart. There is no amount of social grievance against the government that can justify the level of irresponsible ethnocentric hatred currently being peddled by a growing number of disgruntled groups in the country. However, the initial nonchalance and apparent misguided handling by the authorities of the root cause of hate speech in the country is mortifying. This growing trend of hate speech must be condemned in the strongest terms.

The findings of this study turned out rather interestingly. The research methodology was administered within an academic community, the respondents corresponded with most of items presented in the questionnaire rather affirmatively. Nigeria is a federated state with over 250 ethnic groups and 500 languages and from the responses gathered during the field survey, it can be deduced that the survival of our $170+$ million people lies in our ability to curtail conflicting ethnic tensions. We have, however, had instances of conflict along ethno-religious lines, most notably the civil war in the period 1967 to 1970 which saw millions of Nigerian citizens killed. The "us" against "them" rhetoric that ignited bloodshed of a bestial magnitude since independence can be said to have re-surfaced again. A new breed of ethnic entrepreneurs seem hell-bent on causing anarchy for political motives. The lessons of our history are being ignored. Strength in diversity is considered weakness.

From the table on the causes of hate among individuals, a large percentage of the respondents agree with the items presented in this section. This is a clear indication that, even though some respondents chose to disagree, no doubt religious disparities, partisan political affiliations and sentiments, ethnicity, academic achievement and the situation where people are cheated on the basis of socio-economic status are among the many reasons that can cause a stir of hate among individuals in the society. This is consonance with James W. Underhill, (2012) who stressed that "love and hate are socially and culturally constructed. For this reason, hate is historically situated." But more so because hate is a deep and extreme emotional dislike, especially invoking feelings of anger or resentment which can be directed against individuals, groups, entities, objects, behaviors, or ideas. Hatred is often associated with feelings of anger, disgust and a disposition towards hostility. This falls within what adult education seeks to eradicate in the society.

From table on what the implications of language use on individuals are, the respondents agreed to the items presented to them regardless of those who disagreed to the fact that language use whether positive or negative has a lot of implications on individuals in the society which could foster hate and irrational behavior. Language use as agreed by the respondents could lead to negative stereo-tying while agreed that insensitive remarks could also demoralize individuals. It was also agreed that name calling and ridicule could affect a persons character, and of course that vocal bullying or other forms of vocal abuses can seriously reduce a persons self-esteem. All these variables could go a long way to imprinting hate in individuals towards the perpetrators which could result in transferred aggression. As an extension, dehumanization through language can cause serious social avoidance by the victim. This is line with what scholars cited by Wikipedia on Speech as the communication or expression of thoughts through spoken words. Speech production being a multi-stepped process by which thoughts are generated into spoken utterances. Production involves the selection of a ppropriate words and the appropriate form which leads to speech perception which refers to the processes by which humans interpret and understand the sounds used in language. (Wikipedia, 2018).

From the table on what the possible disintegrating socio-economic effects of hatespeech, the respondents agreed to the fact that if left unchecked and addressed properly, hate speech has a host of disintegrating socioeconomic tendencies. These effects can be seen in countries that are still struggling with the devastating aftermath of conflicts that arose as a result of hate and hatespeech. Nigeria's democracy, attained through great sacrifice and loss, now faces its most crucial test of ensuring that citizens are safe wherever they choose to reside, be it in the north-east, north-west, north-central, south-east, south-west, or south-south. It was generally agreed by a high percentage that hate can lead to economic discrimination in terms of education and employment, it could lead to the slow growth of a country in terms of diffusion and development, not to ignore discrimination in terms of polity, social justice, sexual and gender bias. By a long shot however, it was also agreed that if left unchecked, hatespeech could lead the complete annihilation of a people through genocide. This is in line with N. Egbunike et al. (2017) who as writers, that are aware of the effects of such parochial politics in our continent: the ethnic tensions in the early 1970's in Zambia, the animus of ethnic hate in post-apartheid South Africa, the horrors of the Rwandan genocide, the ongoing displacement and insecurity in Burundi and parts of the Democratic Republic of Congo, the post-election ethnic killings in Kenya, etc, are markers of warning of note.

From the table on how committed government is in fostering unity among its geo-political zones, the response in favour of government effort was not absolute yet most of the respondents still agreed that although government 
is trying her best, more can and still needs to be done - as deduced from the amount of respondents that disagreed. Nevertheless, we can agree that government has made efforts to caution perpetrators with the Hatespeech bill that was passed into law in 2017. Government has nonetheless identified hate as a common enemy and recognized the need to united disgruntled factions. On a different note though Government has not really embarked on social media campaigns to sensitize people on the dangers of hatespeech knowing fully that its citizens are social media attendants who readily serve what is provided. It was deduced from the respondents that Government has not organized town hall meetings and community development initiatives through outreaches to reach out to the people at the grassroots when it comes to the issue of hatespeech. Government in its defense has increased security in all its geo-political zones.

From the table on what strategies can be employed to address hatespeech especially to those who are victims of abuse: both verbal and non-verbal, it was agreed by the respondents that the preaching of religious tolerance can help address the issue of hatespeech. Mass media campaigns showing the devastating effects of hatespeech on other countries can go a long way to reduce the spread of hatespeech since it's the most used medium for dissemination in the first place. Bullying, insults, name-calling and other forms of verbal and non-verbal abuses should be punished in schools especially primary and secondary levels and the Parent Teacher Associations including all stakeholders should work in synergy. And finally, the respondents who have in one way or the other been victims of injustice agree that treating people accordingly, regardless of ethnic, gender or socio-economic status can help address the issue of hatespeech and that when all zones are treated equally and fairly in terms of allocations and appointments regardless of size or ethnicity hatespeech and unbridled comments can be checkmated.

\section{Conclusion}

Freedom of speech, though sacrosanct, is not absolute. Our freedom is a shared one, limited by the freedom of others. Citizens must draw the line between free speech and arbitrary spite. For a multi-ethnic state with fault lines such as ours, the lasting solution lies in healing the cleavages that promote ethnic division. This also means the triumph of a national identity that transcends the opportunistic ethnocentric group identity, which has been the bane of Nigeria's nationhood. Clearly, we cannot pretend that all is well with our "federation". We assert that our union can only be saved by transparency, frankness and a deliberate revision of structures and relations. Because of the lack of boldness and the inactions of the past, we have a bad deal of a leprous nation in our hands. As stated by the writers on Ethnic hate speech: Statement from concerned Nigerian writers in N. Egbunike et. al (2017), it is insisted, that there should be no prevarication in this matter. On this note this research seeks to reiterate the call for the truerestructuring of Nigeria in a manner of true federalism. The true federalism will bring about control of resources by various states and certain percentage will be contributed to the centre, since the centre is relatively less in population compare to state where large percentage of people are, I think other features of true federalism that suppose to be addressed, immediate solution should be carried out in term of considering the regions that are suppose to get more states to address imbalance in the system also, the control of the centre should be a rotational system, where everyone will be considered in order to bring about sense of belonging and, hate speech will be gradually eradicated in the society most especially our country Nigeria.

\section{Recommendations}

Nigeria's democracy, attained through great sacrifice and loss, now faces its most crucial test of ensuring that citizens are safe wherever they choose to reside, be it in the north-east, north-west, north-central, south-east, southwest, or south-south.

There is a call on the government of Nigeria to do everything in its power to protect her citizens and avert another spate of useless killings, and to listen to all aggrieved segments in a constructive and productive manner. It is the duty of government to make the country livable just as it is for citizens to work in building a country to which we are all happy to belong. This means an interrogation of our national memory. This research recommends the following:

- Reinstating the teaching of a thorough curriculum of Nigerian history in primary and secondary schools.

- A celebration of our individual cultures and languages to reignite our national ethos.

- The application of justice where rights have been violated.

- Creating grassroot outreaches through adult facilitation on relevant matters.

- Inclusive participation through townhall meetings first at the community level, at the state and the federal levels like the National Conference on Restructuring that as was done during the Goodluck regime in 2014.

- Standard regulations should be made to censor the kind of content that is released in the cyberspace.

\section{References}

Altman A. (1993) Liberalism and Campus Hatespeech: A Philosophical Examination. PDF 
Bill S. (2017), Hatespeech and Inter-ethnic violence in Nigeria. Published October 18, 2017. Retrieved from https://freespeechdebate.com

Cohen-Almagor, R. (2013). Freedom of Expression v. Social Responsibility: Holocaust Denial in Canada. Journal of Mass Media Ethics. 28(1), pp.42-56.

Ethnic hate speech: Statement from concerned Nigerian writers. July 2017.

Igwe, V. O., Ewelum, J. N. (2016), "Adult Education and Information and Communication Technology (ICT) in Nigeria: Challenges and Prospects" Journal of Research \& Method in Education (IOSR-JRME)e-ISSN: 2320 7388,p-ISSN: 2320-737X Volume 6, Issue 4 Ver. II (Jul.- Aug. 2016), PP 62-65www.iosrjournals.org

McConnel M. W. (2012) "The Harm in Hate speech by Jeremy Waldron”. PDF. Oxford University Press, pp. 292. Retrieved 25-03-2018

Petnehazi, I.P. (2012) User-generated hate speech: Analysis, Lesson Learnt, and Policy Implications. The Case of Romania.

Rainie, L and Smith, A (2012) Social networking sites and politics. Pew Research Center: Pew Internet and American Life Project. Available at

http://www.pewinternet.org/files/oldmedia//Files/Reports/2012/PIP_SNS_and_politics.pdf

Toni M. M.(1991) Equality and Freedom of Expression: The Hate Speech Dilemma, 32 Wm. \& Mary L. Rev. 211, http://scholarship.law.wm.edu/wmlr/vol32/iss2/3

The Harm in Hate Speech — Jeremy Waldron | Harvard University Press http://www.hup.harvard.edu/catalog.php?isbn=9780674416864\&content=reviews

The Harm in Hate Speech // Reviews // Notre Dame Philosophical Reviews // University of Notre Dame. https://ndpr.nd.edu/news/the-harm-in-hate-speech/

UNESCO (2015) Countering online hate speech.UNESCO Report, 2015.

Waldron, J. (2012) The Harm in Hate Speech. Harvard University Press. 